\title{
Women's Representation in Bureaucracy: Reservation Policy in Nepali Civil Service
}

\author{
Samjhana Wagle* \\ Central Department of Sociology, Tribhuvan University, Kathmandu, Nepal
}

\begin{abstract}
This paper analyses women's representation in Nepali bureaucracy after the implementation of the reservation policy in 2007. The motivation behind the reservation was that people from marginalized and weaker section of the society should be uplifted. Moreover, representative bureaucracy refers to a bureaucracy that embodies the demographic structure of the society. Following descriptive research method, I collected data from secondary sources such as annual reports and other publications of Public Service Commission, Nepal. The amendment of Civil Service Act-1993 in 2007 with the provision of 45 per cent reservation of civil service seats for women along with indigenous community, Madhesi, Dalit, disabled people and people from backward areas has resulted in the growing number of women's participation. The growing number of women civil servants in the recent years is expected to change the landscape of civil service in near future. Implications for public administration research and practice are discussed.
\end{abstract}

Keywords: inclusion, reservation, representative bureaucracy, demographic composition

* Author Email: wagle.samjhana@gmail.com https://orcid.org/0000-0002-7198-3927
ISSN: 2091-0118 (Print) / 2091-2560 (Online)

(C) 2019 The Author(s).

Journal homepages: ${ }^{1}$ http://www.kusoed.edu.np/journal/index.php/je

${ }^{2}$ https://www.nepjol.info/index.php/JER/index

Published by Kathmandu University School of Education, Lalitpur, Nepal.

This open access article is distributed under a Creative Commons Attribution (CC BY-SA 4.0) license. 


\section{Introduction}

This article is about women's representation in Nepali bureaucracy. It aims to make a contribution to the study of inclusion by analysing the implementation of reservation policy in the bureaucracy of Nepal. Nepali bureaucracy is represented by its civil service employees who work towards implementing the public service delivery policy of the state (Shrestha \& Paudel, 2019). The civil service is an institutional mechanism to support the government in executing its tasks and realising the goals of the country that have been defined under the Directive Principles and Policies of the State in the Constitution of Nepal. The role of civil service is to deliver the services to the people in a speedy, efficient and effective manner. In the changing contexts, the roles and priorities of the government and its civil service alike have been changing. To this end, various efforts have been initiated on behalf the government towards changing its traditional role from the concept of 'feeding people' to 'enabling the people'. With the changing socio-political change in Nepal, several agenda including inclusion (and exclusion) of different groups have been witnessed across social institutions (Dhakal, 2019). Accordingly, during the past several decades, efforts have been made to improve both structures and governance. Inclusive bureaucracy is one of the new concepts of such efforts.

Representative bureaucracy is a key idea in public administration which characterises a civil service mechanism that embodies the demographic configuration of the society (Jamil, 2019). Nepal government aims to make the bureaucracy more representative and inclusive. It is assumed that the inclusiveness in bureaucracy increases the performance in service delivery. In this background the reservation policy was introduced. Although the concept of inclusion is new and there is no consensus on the nature of this construct or its theoretical underpinnings, it has garnered increased attention in recent years.

Nepal is a country of diversity in several aspects such as gender, caste, culture, language, religion and geography binding. There are 125 caste and ethnicity, 92 language spoken and followers of 10 religions (Central Bureau of Statistics, 2014). Reservation is one of the tools of inclusive policy which is mainly focused on increasing representation through the employment of diverse and marginalized people in government. Therefore, inclusive public service is represented by the demographic 
Woman's Representation in Bureaucracy $\mid 29$

composition of the populace it renders it service to (Gidengil \& Vengroff, 1997). Women and marginalized social groups have long been underrepresented in Nepal public sphere and therefore voices for the inclusion of those groups in public institutions, including politics and bureaucracy, have been strongly raised in recent decades, especially by women, aadibashi janajati, madhesi, dalits and other marginalized communities. As a corollary, some provisions for the inclusion of those groups have been partly addressed including in the constitution or other legal documents. Recently, the agenda of inclusion has gained currency in politics, public discourse, development practitioners, and the academicians alike (Dhakal, 2019; Gurung, 2019), which responds to intersectional exclusion (Hasan, 2009). This development has led to greater emphasis on inclusion.

Inclusion is the agenda where exclusion exists. As Luhmann (2005) opines, "It only makes sense to speak of inclusion if there is exclusion" (p. 237). A comprehensive review of the relatable literature (including Kabir, 2013; Pierson, 2010; Sheppard, 2006) shows that the concept of exclusion is not adequately supported by social theory and it is often synonymously used for poverty and marginalization. While many scholars define inclusion differently, I find World Bank's (2003) definition mostly acknowledged, which defines social inclusion as "the removal of institutional barriers and the enhancement of incentives to increase that explains the meaning and to the development opportunities" (p. 256).

As the literature shows that existence of social exclusion is a problem, inclusion is a solution. With this understanding, the policy of reservation is introduced. It is argued that positive discrimination is essential for creating equal grounds for the marginalized and disadvantaged groups (Tan, 2016). The Interim Constitution of Nepal 2007 had included several gender-friendly provisions and inclusive principles, not least the fundamental right of the citizen to social justice. Article 21 has stated that women, dalits, adibasi janajatis, the madheshi community, downtrodden classes, poor farmers, and workers, who have lagged behind, from the economic, social or educational viewpoints, shall have the right to participate in the state structure based on the principle of proportionate representation.

Then, in August 2007, the second amendment to the 1993 Civil Service Act provided for reserving 45 per cent of all vacancies to be fulfilled by way of open 


\section{0 |S. Wagle}

competition and, assuming the vacancies thus reserved to be 100 per cent, fulfilling the same by way of separately-held competitions from among each of the six specified categories of candidates: Women (33 per cent), adibasi janajati (27 per cent), madheshi (22 per cent), dalit ( 9 per cent), persons with disability ( 5 per cent) and those from the backward areas ( 4 per cent). The motivation behind the reservation was that those who are marginalized should be uplifted by creating various opportunities by the nation. Therefore, policies such as inclusion and reservation are for mainstreaming them.

Reservation practice has resulted in the growing number of women's participation. In 2018, the total number of civil servants was 89039, out of which, 21124 were women, which represents nearly 24 per cent. It was only 20 per cent in 2016 and only nine per cent in 2008 when the reservation policy was introduced. Scholars assume that organizations that respect women are more likely to foster an inclusive work climate (Greenan, Lanfranchi, L'Horty, Narcy, \& Pierné, 2019). The growing number of women civil servants in the recent years is expected to change the landscape of civil service in near future. There are various clusters enjoying the policy of inclusiveness. But this article is focused on nation's inclusive policy on bureaucracy for women.

In Nepal, the voice of exclusion/inclusion rose louder in public debate and became the serious concerns of policy makers after the second peoples' movement in 2006. Then, the Interim Constitution of Nepal (2007) stated the term 'proportional inclusion' to address the issue of social justice, to make participation in all organs of the State structure aiming to have all state organs inclusive. On this ground, reservation policy in bureaucracy was initiated. Then the debate on positive and negative aspects of inclusion, reservation policy started. The debate on positive and negative aspects of the policy implementation is obvious. There are some voices on negative effects of the reservation policy. According to Chalam (1990) reservation affects the merit-based selection. Rao and Kelleher (2007) questioned whether reservation works for or against professional advancement. As such, there exist two perceptions in contrast: the perception that inclusion in bureaucracy makes the service delivery effective, and the scepticism on the work performance and whether it has been effective in reducing social exclusion in practice. Hasan (2009) opines that low income, low merit and low productivity are not the causes but the consequences of such exclusion. Khadka and Sunam (2018) opined that affirmative action policies have on the one hand increased women's representation and visibility, and on the other hand, these have also created 
Woman's Representation in Bureaucracy | 31

opportunities for women to express their voice in their organisations leading to institutional transformation.

Some empirical literature has shown that the policy of reservation has resulted in the increment in the representation of women and other excluded groups in Nepali bureaucracy (Chaudhary, 2013; Poudel, 2016; Khadka \& Sunam, 2018). But Chaudhary (2013) concluded that the policy seems to have emerged with top-down approach and thus it has become less effective for bonding, bridging and integrating the excluded groups in the society. Likewise, Poudel (2016) opined that the legal opportunity allocated for inclusion were enjoyed by certain elite families in the name of disadvantaged groups. Dhakal (2013) concluded that women reservation policy has been able to attract them towards civil service as the number of female applicant seems increasing but capacity development programmes are needed to increase their competitiveness.

The implementation of reservation policy in bureaucracy in Nepal has become more than a decade and the preliminary impact of policy can be assessed. Against this background, this paper seeks to examine women representation in Nepali bureaucracy. In order to make inclusive bureaucracy, Nepal Government introduced reservation system, by provisioning the quotas for women, ethnic groups, madhesi, dalit, disabled, and the people belonging to backward areas. This provision has contributed to increase the participation of women and other benefitted groups in the public service. In this scenario, the paper intends to analyse and examine the increased representation of women in civil service of Nepal after the implementation of the reservation policy.

In what follows, the history of reservation policy in Nepal is discussed and arguments for or against reservations are drawn. Then the methods, including the secondary data analysis procedure, are described. The results show an increasing representation of women in Nepal's bureaucracy; however, their representation is narrowed as much as they climb the higher positions. The implications of the findings for public administration research and practice in Nepal conclude the discussion.

\section{History of Reservation Policy in Nepal}

The history of the effort to mainstream marginalized and backward community is comparatively new in Nepal. Inclusive policy in Nepal has often been a response to the demand by women and other marginalized groups for a role in national life (Paudel, 


\section{$32 \mid$ S. Wagle}

2013). Started formally in 2007 focusing on the civil service, a reservation policy in Nepal has emerged as a key driver for developing an inclusive nation-state by promoting inclusion of women and members of marginalized groups in the government employment (Sunam, 2017). Reservation in Nepal is a form of affirmative action designed to improve the participation of under-represented communities demarcated largely by gender, caste, backwardness and disability. The Constitution of the Kingdom of Nepal (1990) acknowledged multiple social and cultural diversities existing in the country. The ensuing development plans made attempted to address the concerns of adibasi janjati and other marginalized groups by establishing a legal framework, initiating institutional development and by launching related programs. The Tenth Plan (2002-2007) has recognized social inclusion as one of strategic pillars of broader poverty reduction strategy.

The Interim Constitution of Nepal (2007) initiated the transformation process in social, political and administrative spheres. The formation of the Constituent Assembly (CA) and the second amendment to the Civil Service Act were some of the exemplary initiatives of the state aimed at ensuring inclusion in political representation and civil service. The political ground that was paved after the election of constitution assembly had tried to address the exclusion problem by mainstreaming the women and other marginalized groups in three levels of governments (local, provincial, federal). The Constitution of Nepal (2015) has stated "women shall have the right to participate in all bodies of the State on the basis of the principle of proportional inclusion and they shall have the right to obtain special opportunity in education, health, employment and social security, on the basis of positive discrimination" (Article 38-4).

Although enhancing the women participation in the civil service was the agreed policy of the Government of Nepal since its commitment in the International Women's year - 1975, and was mentioned in the development plans, the Civil Service Act and its Regulation with its 29 amendments respectively did not speak about the gender vision in the civil service system (Shakya, 2010). The civil service, which is the gateway to employment and decision-making, did not provide gender friendly environment. The impact was women's voice was non-representative, unheard and non-functional in the Nepali bureaucracy (South Asian Coordination Committee for Political Empowerment of Women, 2001). However, when the reservation policy is implemented, women's representation in Nepali bureaucracy is increased and it has mainstreamed women in 
Woman's Representation in Bureaucracy | 33

decision making, policy making and policy implementation phases. These resulted women socially and economically empowered through participation. According to Acharya (2017), Nepali women's participation in major political movements in the history of Nepal has made them politically, socially, and culturally aware. Their active participation helped them challenge the social, cultural, and religious practices that stigmatized Nepali women for ages.

\section{Insights From the Literature}

In the public administration literature, the debate concerning the representation of women and minorities in the public bureaucracy continues to attract significant attention. The idea of reservation for 'backward classes' was first mooted in 1881 by Mahatma Jyotiba Phule, in his statement to the Hunter Commission set up by the British Government to inquire into the status of primary and secondary education in India. It is believed that Chhatrapati Shah was inspired by Jyotiba Phule while implementing his own reservation policy in 1902 (Chavan, 2019). Kingsley (1944) was attributed to contribute originally to the theory of representative bureaucracy, who observed if a workforce reflects the social composition. According to Roch and Pitts (2011), the concept of inclusion is used to "consider whether a public organization employs a bureaucracy that matches the general population or salient indicators of diversity, such as race, ethnicity, or gender" (pp. 392-393).

Social inclusion is about participation especially of the most disadvantaged people who are left out from the mainstream of development and in the governance process (Jackson, 1999). Social inclusion is the process of improving the terms for individuals and groups to take part in the society. It is also a process of improving the ability, opportunity and dignity of people, disadvantaged on the basis of their identity, to take part in society (World Bank, 2013,). In a broad sense, social inclusion means uniting the national and global society consisting of multicultural groups based on the principle of both autonomy and mutual cooperation (Tamang, 2014). Cameron (2006) further argues that due to an inadequate understanding of what is meant by inclusion, the attention has been focused on the problems and deficits of the "excluded" (Cameron, 2006).

The importance of this question is predicated in the belief that promoting representativeness in bureaucracy ensures that diverse communities in the population 


\section{4 | S. Wagle}

are given due share in policy making processes, which in turn causes their preferences to be taken into account (Naff \& Crum, 2000). According to Béland (2007), the idea of social inclusion/exclusion is a framing tool to help the experts and policy makers make sense of the social world and design policies in order to solve the social problems which are realized to be important. India has taken a number of affirmative actions including reservation policy for disadvantaged groups that include SCs, STs, OBCs and other minority groups (Hasan, 2009). She has presented the case of India that has a success story with regard to the inclusion of excluded caste groups, it has been less effective in the effort to facilitate the inclusion of minorities in public institutions, even though minorities as a whole constitute almost 19 percent of the population. After the democratic change in 1952, Indian government upon the request of the government of Nepal sent a team of experts headed by N. M. Buch to suggest reform in the country's administrative system. The commission made a lot of recommendations but it did not suggest, unlike in their own country, reservation in civil service to make the Nepali bureaucracy inclusive (Awasthi \& Adikari, 2012).

As Kranz (1976) notes that representative bureaucracy will "lead not only to more democratic decision-making but to better decisions because it would expand the number and diversity of the views brought to bear on policy making" (p. 110). According to Frazee (2003), people need both opportunities and assurances of welcome to make people socially active. She also argues that inclusion and equality are two distinct and complementary principles where equality stands for rights and inclusion for relationships. In this line, Freiler (2003) argues that social inclusion is the capacity and willingness of a society to keep all groups within the reach of what is expected from the society.

Literature shows that social exclusion has become hindrance for democratization process and to remove such interruption reservation could be rectification tool that helps to make the state inclusive.

\section{Method}

This paper has followed descriptive method. When a particular phenomenon is under study, the research is needed to describe it, to clarify and explain its inner relationships and properties (Huczynski \& Buchana, 2007). The descriptive research outlines a precise profile of people, events or situations highlighting current issues or problems 
Woman's Representation in Bureaucracy | 35

(Fox \& Bayat, 2007) and it further "explains the conditions and circumstances of the cause" (Loeb et al., 2017, p. 1). When the focus is on cause-effect relationships, the study can be explanatory explaining which causes produce which effects (Yin, 2014). This study has highlighted the current issue of gender inclusion by studying the pattern of women representation in Nepali civil service.

The study is based on the secondary data collected from annual reports of Public Service Commission (2016, 2017, 2018 and 2019) and publications of Ministry of Federal Affairs and General Administration Nepal (2008 and 2016). Various published reports, books, journals, and literatures available in the internet are used to review the inclusion literature. The collected data are presented in tabular form and comparison has been made before implementation of reservation policy and now. The effectiveness of policy is measured by examining the number of women's representation in Nepali bureaucracy. To examine the level representation is not sufficient in measuring the effectiveness of policy; but this paper is limited up to the level of describing the pattern of women representation in Nepali civil service.

\section{Major Findings}

A key question in representative bureaucracy research is how well the different social groups are represented in the national bureaucracy. Equally important a question is how the policies, public discourse and implementation pragmatics align in relation to ensuring greater gender representation in bureaucracy. This paper has examined the changing scenario of women's representation in Nepali bureaucracy. It has found that the reservation policy applied by the government has supported to increase women's representation in civil service of Nepal.

Table 1 shows the latest gender-wise composition of civil servants in various service sectors. Although, the overall representation of women in Nepali civil service, as per 2018 data, is 23.72 per cent, all sectors except health (46.94 per cent) and miscellaneous (43.78 per cent) sectors have less than 20 per cent representation of women. 
36 | S. Wagle

Table 1

Total Seat and Number of Civil Servants Nepal

\begin{tabular}{llllllll}
\hline SN & Service Type & $\begin{array}{l}\text { Total } \\
\text { Seat }\end{array}$ & \multicolumn{5}{c}{ Total Number of Working Civil Servants } \\
\cline { 5 - 8 } & & Total & Female & $\begin{array}{l}\text { Female } \\
(\%)\end{array}$ & Male & $\begin{array}{l}\text { Male } \\
(\%)\end{array}$ \\
\hline 1 & Economic & 474 & 406 & 52 & 12.81 & 354 & 87.19 \\
& Planning \& Stat & & & & & & \\
2 & Engineering & 12051 & 8496 & 795 & 13.56 & 7701 & 90.64 \\
3 & Agriculture & 5741 & 4785 & 649 & 13.56 & 4136 & 86.44 \\
4 & Judiciary & 4256 & 3515 & 522 & 14.85 & 2993 & 85.15 \\
5 & Foreign Affairs & 297 & 271 & 54 & 19.93 & 217 & 80.07 \\
6 & Administration & 56510 & 33398 & 4083 & 12.23 & 29315 & 87.77 \\
7 & Auditing & 378 & 349 & 43 & 12.32 & 306 & 87.68 \\
8 & Forest & 7038 & 5870 & 583 & 9.93 & 5287 & 90.07 \\
9 & Education & 1834 & 1632 & 290 & 17.77 & 1342 & 82.23 \\
10 & Health & 32986 & 26785 & 12574 & 46.94 & 14211 & 53.06 \\
11 & Parliament & 433 & 250 & 42 & 16.80 & 208 & 83.20 \\
12 & Miscellaneous & 5493 & 3282 & 1437 & 43.78 & 1845 & 56.22 \\
\hline Total & & 127491 & 89039 & 21124 & 23.72 & 67915 & 76.28 \\
\hline
\end{tabular}

(Source: Public Service Commission, 2018)

Table 1 illustrates that women's representation in health service and miscellaneous is over forty per cent but in the remaining field, their representation is less than twenty per cent. This shows that women representation has been inconsistent across sectors and that this might also has resulted due to women's interest in some particular sectors (e.g. health) than others. This also indicated the necessity to adopt some systematic approach to addressing women's representation across sectors in Nepali bureaucracy. The following figure better illustrates the share of women in different service types in the year 2018.

Journal of Education and Research, Vol. 9, No. 2, 2019 


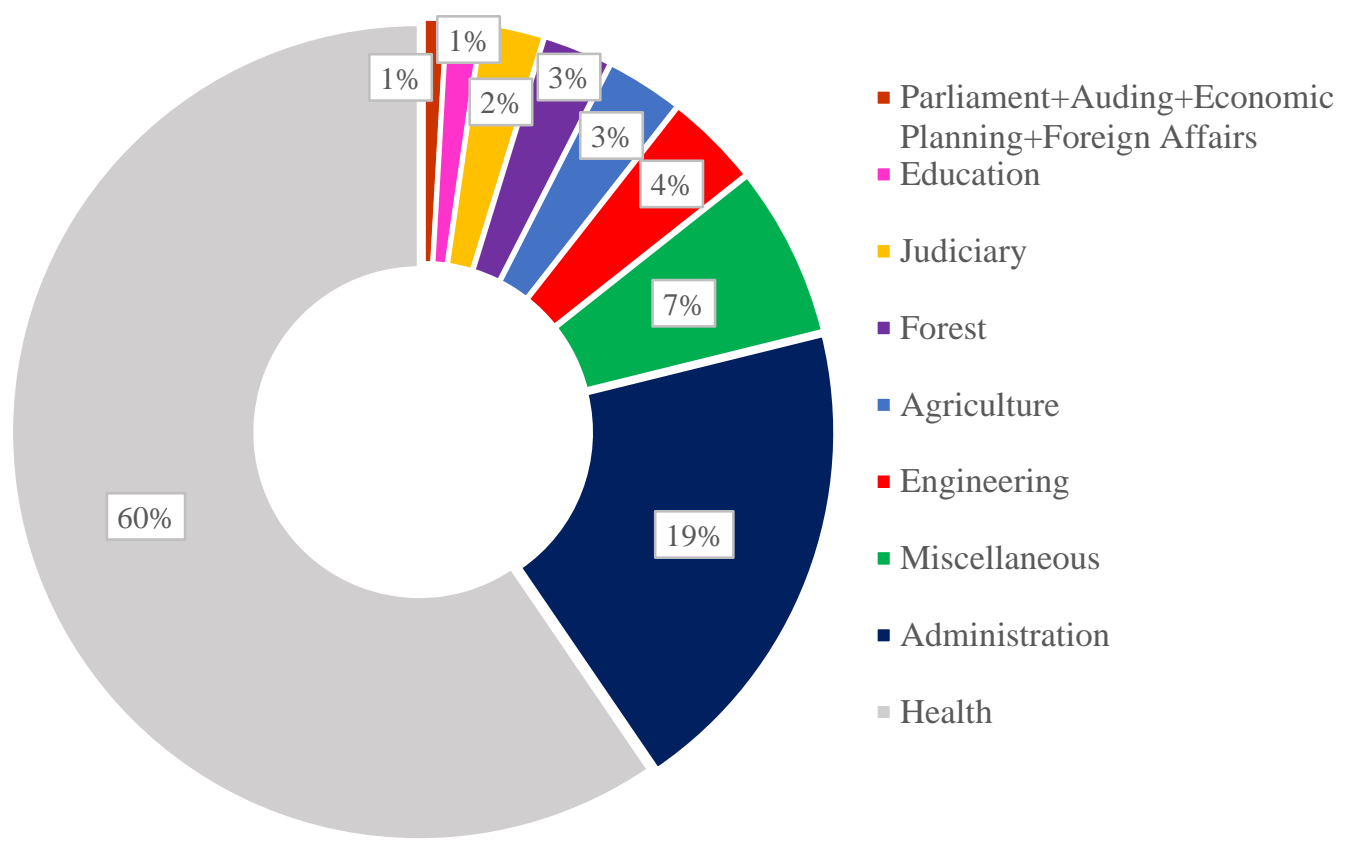

Figure 1. Women representation in service types - 2018.

In total, women's representation in bureaucracy is very low (23.72 per cent) in comparison with the total female population (51.5 per cent) of Nepal. Kingsley (1944) opined that public workforce should reflect the social-class composition of the people it serves. Likewise, Roch and Pitts (2011) have also emphasised whether a public organization employs a bureaucracy that matches the general population or salient indicators of diversity, such as race, ethnicity, or gender. However, gender participation in Nepali civil service does not reflect that. Nevertheless, if we compare the current statistics (23.72 per cent) with the ratio ten years ago ( 9 per cent), the result is quite optimistic in terms of representing women in bureaucracy.

The Public Service Commission has been implementing the representative recruitment policy for various six groups. Table 2 shows the trend and scenario of inclusive Nepali bureaucratic composition for the past eight years. The data shows the increasing representation of women in Nepali bureaucracy. In 2010, the candidates recommended from the women quota were only 471 but in 2017 the number has risen to 1088 . 
38 | S. Wagle

Table 2

Number of Candidates Recommended as Per Free-Competition and Reservation Policy

\begin{tabular}{|c|c|c|c|c|c|c|c|c|}
\hline \multirow{2}{*}{$\begin{array}{l}\text { Fiscal } \\
\text { Year }\end{array}$} & \multirow{2}{*}{$\begin{array}{l}\text { Under Free } \\
\text { Competition }\end{array}$} & \multicolumn{7}{|c|}{ Under Reservation Policy } \\
\hline & & Total & Women & Indigenous & Madhesi & Dalit & $\begin{array}{l}\text { Diff. } \\
\text { Able }\end{array}$ & $\begin{array}{l}\text { Back } \\
\text { warded } \\
\text { area }\end{array}$ \\
\hline 2010/11 & 2487 & 1349 & 471 & 371 & 300 & 105 & 59 & 43 \\
\hline 2011/12 & 1805 & 1013 & 352 & 280 & 212 & 99 & 40 & 30 \\
\hline 2012/13 & 1707 & 1136 & 372 & 318 & 254 & 106 & 51 & 35 \\
\hline 2013/14 & 2767 & 1854 & 626 & 509 & 384 & 173 & 91 & 71 \\
\hline 2014/15 & 2783 & 1979 & 639 & 547 & 454 & 168 & 95 & 76 \\
\hline 2015/16 & 3300 & 2338 & 797 & 629 & 503 & 213 & 101 & 95 \\
\hline 2016/17 & 5273 & 4026 & 1383 & 1026 & 901 & 385 & 189 & 142 \\
\hline 2017/18 & 4007 & 3224 & 1088 & 858 & 711 & 292 & 163 & 132 \\
\hline Total & 24129 & 16939 & 5728 & 4538 & 3719 & 1541 & 789 & 624 \\
\hline
\end{tabular}

(Source: Public Service Commission, 2018)

Although the ratio of women candidate to total recruitment is nearly the same, the number has increased. Moreover, with the increase in women candidates, Nepali bureaucracy is inching forward towards minimizing gender parity - though current efforts are only the beginnings. In fact, an inclusive bureaucracy reflects the demographic composition of society which in turn will make every voice audible and equal share in decision-making process as well as ownership of agenda and accountability for the same (Selden, 1998). The issue of representation and staffing carries important implications for the delivery of public services, the sharing of power in a society as well as it symbolizes equal opportunities and equity (Groeneveld \& Van de Walle, 2010; cf. Wimmer, 1997). As the data displayed, the number is increasing, which means this increasing number is supposed to contribute to setting the gender friendly agenda.

As the data show, the number of women participation has been increased but their representation in the gazetted classes is very low (Table 3). In 1991, women's representation in special class was three per cent and in 2016 it sharply declined to nil. In non-gazetted group, women's representation in 1991 and 2000 was only eight per cent and in 2016, it rose to 14 per cent.

Journal of Education and Research, Vol. 9, No. 2, 2019 
Table 3

Women's Representation in Civil Service by Class and Level

Level

Special Class

First Class (Gazetted)

Second Class (Gazetted)

Third Classed (Gazetted)

Non Gazetted

Total
Women's Representation in Percentage

\begin{tabular}{ccc}
\hline 1991 & 2000 & 2016 \\
\hline 3 & 2 & 0 \\
5 & 4 & 5 \\
5 & 3 & 5 \\
5 & 5 & 10 \\
8 & 8 & 14 \\
8 & 8 & 20
\end{tabular}

(Source: Ministry of General Administration, 2008, 2016)

While analysing the data of women representation in different classes and levels of Nepali civil service, the 2016 statistics reveals that as the women move to the upper levels and classes, their representation is narrower. Figure 2 illustrates this scenario.

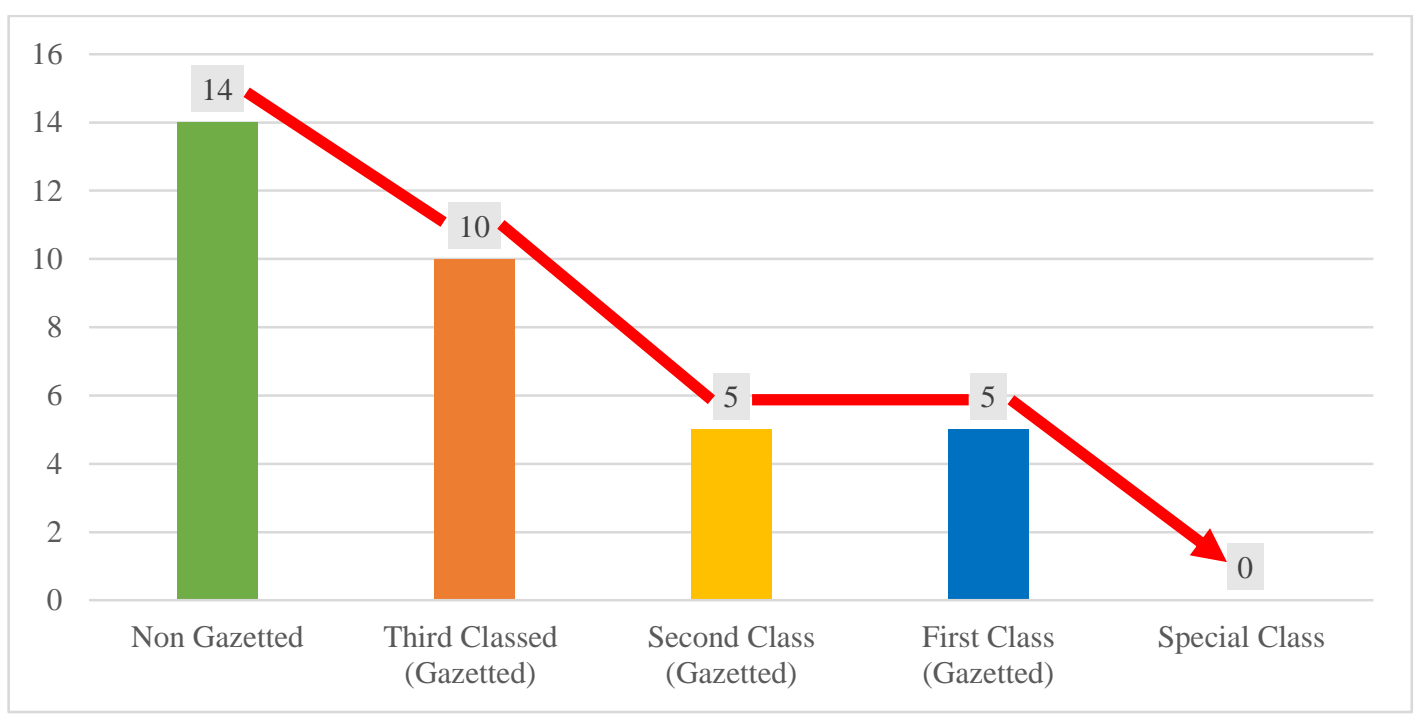

Figure 2. Women in different class/levels of Nepali civil service (2016).

The results match with the study of Acharya (2017) which concluded that women's political participation and representation have increased, but not in executive positions. Negligible representation in higher level post shows no role of women in decision 
40 | S. Wagle

making and policy making level. This has weakened in making gender friendly policy. As Hasan (2009) opines that low merit or low productivity are not the causes but the consequences of such exclusion. Although, there is quota even in higher post for women in both promotion and lateral entry provision but this couldn't result significant success. It shows the need of further capacity development program for them.

Although women's representation in the higher level of civil service is low, the trend of woman applicants for these posts is found increasing. Table 4 shows the ratio of woman applicants at various levels for the last three years.

Table 4

Woman Applicants in Civil Service by Class and Level of Last 3 Years

Level

$2016 / 17$

$2017 / 18$

$2018 / 19$

Total Women Total Women Total Women

$\% \quad \%$

First Class (Gazetted)

2216

12.7

1822

15.8

198

29.8

Second Class (Gazetted)

6917

22.4

6831

21.4

1048

30.8

Third Class (Gazetted)

67019

$37.8 \quad 74089$

41

14344

42.3

First Class Non-Gazetted

184200

$43.8 \quad 136884$

47.2

63456

49.8

Second Class Non-Gazetted

227274

51.2198802

50

64733

50

Source: Annual Reports of Public Service Commission, 2016/17, 2017/18 \& 2018/19

In 2016/17, the percentage of women applicants for the first class (Gazetted) was 12.7 per cent and in 2018/19 it became 29.8 per cent. Likewise, in the second class (Gazetted), the ratio of woman applicants was 22.4 in 2016/17 and it became 30.8 per cent in 2018/19. Though the number of women in the Gazetted class is not satisfactory, the scenario of women applicants shows optimistic results.

The women applicants in other classes are also increasing. Table 5 shows gender wise applicants for civil service in the last 12 years. Although the proportion of women applicants seems fluctuating, numbers of women applicants for civil service are increasing for the last 10 years. In 2007/8, women applicants consisted of 38.50 per 
Woman's Representation in Bureaucracy | 41 cent of total applicants whereas their number reached 60.12 per cent in 2014/15 and 49 per cent in 2018/19.

Table 5

Gender-wise Trend of Applicants for Civil Service in the Last 12 Years

\begin{tabular}{cccccc}
\hline \multirow{2}{*}{ Fiscal Year } & Total & \multicolumn{2}{c}{ Female } & \multicolumn{2}{c}{ Male } \\
\cline { 3 - 6 } $2007 / 8$ & & Number & $\%$ & Number & $\%$ \\
\cline { 3 - 6 } $2008 / 9$ & 175122 & 67435 & 38.50 & 107677 & 61.5 \\
$2009 / 10$ & 36168 & 32457 & 37.67 & 53711 & 62.33 \\
$2010 / 11$ & 251651 & 110307 & 43.83 & 141344 & 56.17 \\
$2011 / 12$ & 271577 & 113785 & 41.90 & 157792 & 58.10 \\
$2012 / 13$ & 368805 & 173418 & 47.02 & 195387 & 52.98 \\
$2013 / 14$ & 560915 & 255234 & 45.50 & 305681 & 54.50 \\
$2014 / 15$ & 599668 & 360506 & 60.12 & 239162 & 39.88 \\
$2015 / 16$ & 595031 & 318503 & 53.53 & 275877 & 46.36 \\
$2016 / 17$ & 844297 & 382485 & 45.30 & 461812 & 54.70 \\
$2017 / 18$ & 567853 & 296704 & 52.25 & 271149 & 47.75 \\
$2018 / 19$ & 143840 & 70578 & 49.1 & 73175 & 50.9 \\
\hline
\end{tabular}

(Source: Public Service Commission, 2019)

It is a very positive change in the public service of Nepal. The growing proportion of female candidates is also because of increasing interest and confidence of female in sitting for exams of the Public Service Commission (PSC). Though there is increment in number of female applicants, there is no sufficient ground for being satisfied as the percentage of candidates passing the PSC exams are still been dominated by the males. The major reason behind it could be the structural hindrance of our society that has resisted women in many ways. It has further been explained in the next section. 


\section{Discussion and Conclusion}

Following the reservation policy, women's entry in the civil service of Nepal has increased from 8 per cent in 2008 to 24 per cent in 2018. Since the civil service is meant as the arm of the executive branch of government and if it is inclusive the service provided by the government is supposed to be more effective. The provision of the quota system has resulted in the growing representation of women in recent year but the overall proportion of women in civil service is still very low ( 24 per cent only). Among the service sectors, the participation of women in health sector is more than sixty per cent but in other sectors it is less around 15 per cent (Table 1).

The increasing trend of women participation and interest in the civil service can be attributed to the policy and practices of reservation policies in the country. It also reflects the growing interest and confidence of women in civil service. The growing percentage of women applicants for the first and second class (Gazetted) level support this fact (Table 4). Although the female applicants are increasing, the number of women in senior level post has not significantly increased (Table 3). The major reason behind it could be the structural hindrance of our society that has resisted women in many ways. For example, comparatively early age marriage of women than men (Maharjan, Karki, Shakya, \& Aryal, 2012), compulsion in engaging household chores, caring of children if she has etc. been some constraining issues that Nepali women are facing (Baidya, Dhungana, \& Kattel, 2006). As Hasan (2009) opines, low-merit and low productivity are not the causes but the consequences of such exclusion. From this, we can suggest that further capacity enhancement programme by removing such structural hindrance is needed to make women more competitive.

This research found that reservation policies adopted by the government in bureaucracy has resulted the increment of women representation in civil service. In fact, very few women have been able to enter the service without reserved quotas. Although women's participation is increasing, their lower representation in higher post depicts a dismal picture. It means women civil servants do not have access to decision making and policy making level yet - they need to fight a variety of odds to advance in their career (Kabir, 2013). Apart from this, private sector and other non-government organizations (NGOs) have also been following the government policy. That has increased the participation of women in public sphere. 
Woman's Representation in Bureaucracy | 43

One of the key intents behind representativeness is to ensure democratic and inclusive characteristics of bureaucracy (Jamil, 2019) so that it reflects different interests of the community (Selden, 1998; Shrestha \& Paudel, 2019). It not only mainstreams the excluded gender, ethnicity and back warded communities but also promotes their social and economic condition. As Dhakal (2013) concluded, only quota reservation is not sufficient but other capacity development programmes are needed to increase their competitiveness. Therefore, in order to increase women's participation in higher levels, further capacity enhancement programmes should be carried out in parallel.

This reservation policy adopted by the Nepal Government for mainstreaming and empowering the marginalized caste, ethnicity and gender has resulted the positive impact. The study shows that women's quantitative representation has been somehow ensured in Nepali bureaucracy. However, the current provisions should be taken as a beginning only since a long road is yet to be travelled so as to ensure gender equality across different sectors in Nepal. An imminent step that would promote this practice further could be provisioning equal percentage of quota for male and female across the identified categories, including adibasi janajati, madheshi, dalit, persons with disability and those from the backward areas, besides elevating general quota for women. A study by Meier and Nicholson-Crotty (2006) found that higher level of representation of women in local law enforcement has increased the effectiveness of implementation. What has been in the case of Nepal? Is the increasing representation of women or inclusive bureaucracy has resulted in effective work performance? Has it improved the service delivery? These are the issues to be studied. Given the rationale and voice for inclusive bureaucracy, the discussion raised in this study can be of interest to both academics and policymakers in the field of civil service and public administration in Nepal.

\section{References}

Fox, W. \& Bayat, M. S. (2007). A guide to managing research. Cape Town, South Africa: Juta Academic.

Loeb, S., Dynarski, S., McFarland, D., Morris, P., Reardon, S., \& Reber, S. (2017). Descriptive analysis in education: A guide for researchers. Retrieved from https://files.eric.ed.gov/fulltext/ED573325.pdf 
44 | S. Wagle

Acharya, M. (2017). Nepal Himalaya: Women, politics, and administration. Journal of International Women's Studies, 18(4), 197-208. Retrieved from http://vc.bridgew.edu/jiws/vol18/iss4/14

Awasthi, G. D., \& Adhikary, R. (2012). Changes in Nepalese civil service after the adoption of inclusive policy and reform measures. Lalitpur, Nepal: SPCBN/UNDP. Baidya B. G., Dhungana, M., \& Kattel, R. (2006). The linkages between women's employment, family welfare and child labour in Nepal (Working Paper No. 12). Geneva, Switzerland: Gender Promotion Programme, International Labour Office. Béland, D. (2007). The social exclusion discourse: Ideas and policy change. Policy \& Politics, 35, 123-139.

Bloom, H. (2002). Can the United States export diversity? Across the Board, 47-51.

Cameron, C. (2006). Geographies of welfare and exclusion: Social inclusion and exception. Progress in Human Geography, 30, 396-404 https://journals.sagepub.com/doi/10.1191/0309132506ph614pr

Central Bureau of Statistics. (2014). Population monograph of Nepal (Vol. 1). Kathmandu, Nepal: Author.

Chalam, K. S. (1990). Caste reservations and equality of opportunity in education. Economic and Political Weekly, 2333-2339.

Chavan, A. (2019, January 17). The first reservations in India. Retrieved from https://www.livehistoryindia.com/history-daily/2019/01/17/the-first-reservations-inindia

Chaudhary, S. S. (2013). Social inclusion in civil service through Public Service Commission, Nepal. School of Applied \& Social Sciences, Singhania University, Jhunjhunu, Rajasthan, India

Dhakal, D. (2013). Analyzing reservation policies in civil service of Nepal. Retrieved from http://www.pp.u-tokyo.ac.jp/grasppold/courses/2013/documents/5140143_10a.pdf

Dhakal, R. K. (2019). Promoting gender inclusive governance to deliver better education in Nepal. International Journal of Social Sciences \& Educational Studies, 6(1), 83-95. https://doi.org/10.23918/ijsses.v6i1p83

Frazee, C. (2003). Thumbs up! Inclusion, rights and equality as experienced by youth with disabilities. Toronto, Canada: The Laidlaw Foundation.

Journal of Education and Research, Vol. 9, No. 2, 2019 
Woman's Representation in Bureaucracy 45

Freiler, C. (2003). Foreword: The Laidlaw Foundation's perspective. In C. Frazee (Ed.), Thumbs up! Inclusion, rights and equality as experienced by youth with disabilities (pp. vii-x). Torronto, Canada: Laidlaw Foundation.

Gidengil, E., \& Vengroff, R. (1997). Representative bureaucracy, tokenism and the glass ceiling: The case of women in Quebec municipal administration. Canadian Public Administration/Administration Public Du Canada, 40(3), 457-480. https://doi.org/10.1111/j.1754-7121.1997.tb01519.x

Groeneveld, S., \& Van de Walle, S. (2010). A contingency approach to representative bureaucracy: Power, equal opportunities and diversity. International Review of Administrative Science, 76(2), 239-258. https://doi.org/10.1177/0020852309365670

Greenan, N., Lanfranchi, J., L'Horty, Y., Narcy, M., \& Pierné, G. (2019). Do competitive examinations promote diversity in civil service? Public Administration Review, 79(3), 370-382. https://doi.org/10.1111/puar.13053

Hasan, J. (2009). Politics of inclusion, caste, minorities, and affirmative action. Oxford, England: Oxford University Press.

Huczynski, A. A., \& Buchanan, D. A. (2007). Organizational behaviour. An introductory text (6th ed.). Oxford, England: Pearson Education.

Jackson, C. (1999). Social exclusion and gender: Does one size fit all? European Journal of Development Research, 11(1), 125-146.

https://doi.org/10.1080/09578819908426730

Jamil, I. (2019). The promise of representative bureaucracy and citizen's trust in the civil service in Nepal. In I Jamil, T. N. Dhakal, \& N. R. Paudel (Eds.), Civil service management and administrative systems in South Asia (pp. 121-147). Cham, Switzerland: Palgrave Macmillan. https://doi.org/10.1007/978-3-319-90191-6_6 Khadka, M., \& Sunam, R. (2018). Workforce diversity and reservation policy in Nepal: A strategy approach to strengthening women's voice and visibility in formal employment sector. Retrieved from https://www.ilo.org/wcmsp5/groups/public/--dgreports/---dcomm/documents/publication/wcms_616209.pdf

Kingsley, J. D. (1944). Representative bureaucracy. Yellow Springs, OH: Antioch Press.

Government of Nepal. (1993). Civil service act 1993. Kathmandu, Nepal: Author. Government of Nepal. (1994). Civil service rules 1994. Kathmandu, Nepal: Author. Government of Nepal. (1990). Constitution of Nepal, 2047. Kathmandu, Nepal: Author. 
46 | S. Wagle

Government of Nepal. (2007). Interim constitution of Nepal, 2063. Kathmandu, Nepal: Author.

Gurung, O. (2019). Social inclusion/exclusion: Policy discourse in Nepal. In M. Sekher \& R. Carciumaru (Eds.), Including the excluded in South Asia: Power, politics and policy perspectives from the region (pp. 39-55). Gateway East, Singapore: Springer.

Kabir, S. L. (2013). Key issues in women's representation in bureaucracy: Lessons from South Asia. Public Organization Review, 13(4), 427-442.

https://doi.org/10.1007/s11115-013-0261-8

Luhmann, N. (2005). Inklusion und exklusion [Inclusion and exclusion]. In N. Luhmann (Ed.), Soziologische aufkla “rung 6 [Sociological enlightenment 6] (pp. 226-251). Wiesbaden, Germany: VS-Verlag.

Maharjan R. K., Karki, K. B., Shakya, T. M., \& Aryal, B. (2012). Child Marriage in Nepal-Research report. Kathmandu, Nepal: Plan Nepal, Save the Children Nepal and World Vision International Nepal.

Merriam, S. B. (1998). Qualitative research and case study applications in education. San Francisco, CA: Jossey-Bass.

Meier, K. J., \& Nicholson-Crotty, J. (2006). Gender, representative bureaucracy, and law enforcement: The case of sexual assault. Public Administration Review 66(6), 850-860. https://doi.org/10.1111/j.1540-6210.2006.00653.x

Naff, K. C., \& Crum, J. (2000). The president and representative bureaucracy: Rhetoric and reality. Public Administration Review, 60(2), 98-110.

https://doi.org/10.1111/0033-3352.00069

National Planning Commission. (2002). Tenth plan (2002-2007). Kathmandu, Nepal: Author.

Paudel, B. (2013). Inclusion in civil service: Issues and initiatives. Lalitpur, Nepal: MoGA-UNDP.

Pierre, J., \& Rothstein, B. (2011). Reinventing Weber: The role of institutions in creating social trust. In P. Lægreid \& T. Christensen (Eds.), The Ashgate research companion to new public management (pp. 405-416). Burlington, NJ: Ashgate.

Pierson, J. (2010). Tackling social exclusion. New York, NY: Routledge.

Public Service Commission. (2016). 57th annual report. Kathmandu, Nepal: Author.

Public Service Commission. (2017). 58th annual report. Kathmandu, Nepal: Author.

Public Service Commission. (2018). 59th annual report. Kathmandu, Nepal: Author.

Public Service Commission. (2019). 60th annual report. Kathmandu, Nepal: Author.

Journal of Education and Research, Vol. 9, No. 2, 2019 
Woman's Representation in Bureaucracy $\mid 47$

Rao, A., \& Kelleher, D. (2007). Samajik samabeshikaranko madhyamko rupma sakaratmak vibhed: Bhram ra yathartha [Positive discrimination as a means to social inclusiveness: Myth and reality]. In P. Basnet \& S. Darnal (Eds.), Vishesh adhikar ra arachhenko rajniti [Special rights and the politics of reservation]. Kathmandu, Nepal: Jagaran Media Centre.

Roch, C. H., \& Pitts, D. W. (2011). Differing effects of representative bureaucracy in charter schools and traditional public schools. The American Review of Public Administration, 42(3), 282-302. https://doi.org/10.1177/0275074011400404

Rubin, H. J., \& Rubin, I. S. (1995). Qualitative interviewing. Thousand Oaks, CA: Sage.

Shakya, A. (2008). Few women in Nepalese foreign service. Retrieved from http://www.gorkhapatra.org.np/detail.php?article_id=29141\&cat_id=7

Sheppard, M. (2006). Social work and social exclusion. Aldershot, England: Ashgate. Shrestha, S. K., \& Paudel, N. R. (2019). Civil service management in Nepal. In I Jamil, T. N. Dhakal, \& N. R. Paudel (Eds.), Civil service management and administrative systems in South Asia (pp. 99-119). Cham, Switzerland: Palgrave Macmillan. https://doi.org/10.1007/978-3-319-90191-6_5

South Asian Coordination Committee for Political Empowerment of Women. (2001). Workshop regarding present position of women in the civil service. Retrieved from www.capwip.org/activities/women-civilservice-report.doc

Selden, S. C. (1997). The promise of representative bureaucracy. Armonk, NY: M.E. Sharpe.

Sunam, R. (2017). Debating reservation in Nepal: Unpacking reservation for Dalits in the civil service for the informed policy debate. Report submitted to Swiss Agency for Development and Cooperation, Nepal.

Tamang, M. S. (2014). Perspective on social inclusion and implication for research in Nepal. In O. Gurung, M. S. Tamang, \& M. Turin (Eds.), Perspectives on social inclusion and exclusion in Nepal (pp. 11-57). Kathmandu, Nepal: Central Department of Sociology/Anthropology, Tribhuvan University.

Tan, N. (2016, June 24). Are gender quotas helping female politicians in Asia?

Retrieved from https://www.eastasiaforum.org/2016/06/24/are-gender-quotashelping-female-politicians-in-asia/

Wimmer, A. (1997). Who owns the state? Understanding ethnic conflict in post-colonial societies. Nations and Nationalism, 3(4), 631-665.

Journal of Education and Research, Vol. 9, No. 2, 2019 
48 | S. Wagle

World Bank. (2013). Inclusion matters: The foundation for shared prosperity. Washington, DC: Author.

Yin, R. K. (2014). Case study research: Design and methods (5th ed.). Thousand Oaks, CA: Sage.

\section{To cite this article:}

Wagle, S. (2019). Woman's representation in bureaucracy: Reservation policy in Nepali civil service. Journal of Education and Research, 9(2), 27-48. https://doi.org/10.3126/jer.v9i2.30461

Journal of Education and Research, Vol. 9, No. 2, 2019 